ISSN. 2775-4324 (Online)

Journal of Physical Activity and Sports

Volume 2, Nomor 2, Agustus 2021, 264-273

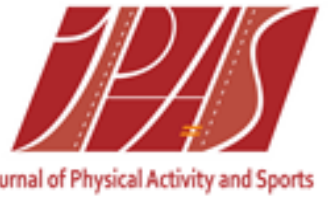

\title{
Peningkatan Kemampuan Psikomotorik Siswa Dalam Pembelajaran Bola Voli Passing Atas Menggunakan Teknik Bola Pantul Pada Siswa Kelas X Man 1 Kota Semarang
}

\author{
Angga Pratama ${ }^{1 *}$, Utvi Hinda Zhannisa ${ }^{2}$, Ibnu Fatkhu Royana ${ }^{3}$ \\ ${ }^{123}$ Universitas PGRI Semarang., Jln Gajah Raya No, 40, Semarang, 50166 \\ * Coressponding Author. E-mail: Gajah7695@gmail.com
}

\begin{abstract}
Education is a very important field, especially in Indonesia. In the language of the definition of education is the process of changing the attitudes and behavior of a person or group of people in an effort to mature humans through teaching and training efforts that are in accordance with the educational procedure itself. The purpose of this study was to determine the improvement of students' psychomotor abilities in learning volleyball using the bounce ball technique in class X students in MAN 1 Semarang City. The design used in this study belongs to the type of quantitative research. The use of a quantitative approach with pre-experimental methods. The population in this study were students of class X in MAN 1 Semarang City. The research sample was taken by means of random sampling. This research will involve 106 students of MAN 1 Semarang City. Based on the calculation, the sig value for pretest data obtained the sig value $=0.064>0.05$. For the posttest data, the sig $=0.056>0.05$ was obtained, so it can be concluded that the pretest and posttest data are homogeneous. The increase in the ability of pretestball voly passing is a minimum of $82,675 \%$. for a maximum value of $89.33 \%$. Data analysis and discussion obtained the following conclusions: There are differences in the psychomotor abilities of students in learning volleyball passing over before and after being given training using the bouncing ball technique in class $\mathrm{X}$ MAN 1 Semarang City. From these results it can be concluded that there is an increase in the psychomotor abilities of students in learning volleyball passing over using the bouncing ball technique in class X MAN 1 Semarang City students. The increase in the percentage of over passing ability is $22.38 \%$. It is better if the class $\mathrm{X}$ student coaches of MAN 1 Semarang City apply exercises using the bouncing ball technique considering that this exercise has been proven effective in improving students' psychomotor skills in learning volleyball passing over.
\end{abstract}

Keywords: Psychomotor, Bounce Ball, Upper Passing, Volleyball.

\begin{abstract}
Abstrak
Pendidikan merupakan bidang yang sangat penting terutama diIndonesia. Secara bahasa definisi pendidikan adalah proses pengubahan sikap dan tata laku seseorang atau kelompok orang dalam usaha mendewasakan manusia melalui upaya pengajaran dan pelatihan yang sesuai prosedur pendidikan itu sendiri. Tujuan dari penelitian ini adalah untuk mengetahui peningkatan kemampuan psikomotor siswa dalam pembelajaran bola voli pasing atas menggunakan teknik bola pantul pada siswa kelas X di MAN 1 Kota Semarang. Desain yang digunakan dalam penelitian ini termasuk dalam jenis penelitian kuantitatif. Penggunaan pendekatan kuantitatif dengan metode pre eksperimen. Populasi dalam penelitian ini adalah siswa kelas X yang ada di MAN 1 Kota Semarang. Sampel penelitian diambil dengan cara random sampling, Penelitian ini akan melibatkan 106 siswa MAN 1 Kota Semarang. Berdasarkan perhitungan diperoleh Nilai sig untuk Data pretes diperoleh nilai sig = $0,064>0,05$. Untuk data posttest diperoleh nilai sig $=0,056>0,05$ jadi dapat disimpulkan data pretest dan posttes homogen. Peningkatan kemampun pretestbola voly passingatas minimum $82.675 \%$. untuk nilai maksimum $89.33 \%$.Analisis data dan pembahasan diperoleh simpulan sebagai berikut:Terdapat perbedaan kemampuan psikomotorik siswa dalam pembelajaran bola voli passing atas sebelum dan sesudah diberi latihan Menggunakan teknik bola pantul pada siswa kelas X MAN 1 Kota Semarang. Dari hasil tersebut dapat disimpulkan bahwa ada peningkatan kemampuan psikomotorik siswa dalam pembelajaran bola voli passing atas menggunakan teknik bola pantul pada siswa kelas X MAN 1 Kota Semarang. Peningkatan persentase kemampuan passing atas sebesar 22,38\%.Sebaiknya pelatih siswa kelas X MAN 1 Kota Semarang menerapkan latihan menggunakan teknik bola pantul mengingat latihan ini terbukti efektif dalam meningkatkan kemampuan psikomotorik siswa dalam pembelajaran bola voli passing atas.
\end{abstract}

Kata kunci: Psikomotorik, Bola Pantul, Passing Atas, Bola Voli. 
Peningkatan Kemampuan Psikomotorik Siswa Dalam Pembelajaran

Bola Voli Passing Atas Menggunakan Teknik Bola Pantul

Pada Siswa Kelas X Man 1 Kota Semarang

Angga Pratama, Utvi Hinda Zhannisa, Ibnu Fatkhu Royana

\section{PENDAHULUAN}

Pendidikan merupakan bidang yang sangat penting terutama diIndonesia. Secara bahasa definisi pendidikan adalah proses pengubahan sikap dan tata laku seseorang atau kelompok orang dalam usaha mendewasakan manusia melalui upaya pengajaran dan pelatihan yang sesuai prosedur pendidikan itu sendiri.

Undang-Undang No. 20 tahun 2003 tentang Sistem Pendidikan Nasional menyatakan bahwa: "Pendidikan adalah sebuah usaha yang dilakukan secara sadar dan terencana untuk mewujudkan suasana belajar dan proses pembelajaran agar peserta didik secara aktif mengembangkan potensi dirinya untuk memiliki kekuatan spiritual keagamaaan, pengendalian diri, kepribadian, kecerdasan, akhlak mulia, serta ketrampilan yang diperlukan dirinya, masyarakat, bangsa, dan Negara.”

Menurut Soekidjo Notoatmodjo, 2003: 16 mendefinisikan secara umum "Pendidikan adalah segala upaya yang direncanakan untuk mempengaruhi orang lain baik individu, kelompok, atau masyarakat sehingga mereka melakukan apa yang diharapkan oleh pelaku pendidikan". Tujuan pendidikan dalam liberalisme adalah mengubah dan membangun tatanan sosial baru.Pendidikan bukan alat tetapi pelaku penyusun, pelaku tatanan sosial baru yang dominan bukan lagi guru melainkan peserta didik. Guru hanya bersifat sebagai fasilitator. Peserta didik bukan mereproduksi ilmu, tetapi memproduksi ilmu. Dari perkembangannya, pendidikan sebagai sarana sosialisasi telah berlangsung sesuai dengan tuntutan setiap zaman yang berbeda-beda dan sesuai dengan ideologi, tujuan serta sistem penyampaiannya (Utomo Dananjaya, 2010: 6). Pendidikan merupakan sarana penting untuk meningkatkan kualitas sumber daya manusia (SDM) dalam menjamin keberlangsungan pembangunan suatu bangsa. Jika pendidikan merupakan salah satu intrumen utama pengembangan SDM, tenaga pendidik dalam hal ini guru sebagai salah satu unsur yang berperan penting didalamnya, memiliki tanggungjawab untuk mengembangkan tugas dan mengatasi segala permasalahan yang muncul. Guru merupakan komponen yang sangat menentukan dalam implementasi proses pembelajaran di dalam kelas sebagai unsur mikro dari suatu keberhasilan pendidikan (Susanto,2013:1).

\section{METODE}

\section{Desain Penelitian}

Penelitian ini menggunakan design penelitian pre eksperimen. Pre eksperimenmerupakan penelitian yang dimaksudkan untuk mengetahui ada tidaknya akibat dari "sesuatu" yang dikenakan pada subyek selidik (Suharsimi, 2005: 207).Desain penelitian yang digunakan dalam penelitian ini 
adalah bentuk One Group Pretest Posttest Design, suatu teknik untuk mengetahui efek sebelum dan sesudah pemberian perlakuan.

\section{Populasi dan Sampel}

1. Populasi

Menurut Sugiyono (2010:117) populasi adalah wilayah generalisasi yang terdiri atas: obyek/subyek yang mempunyai kualitas dan karatristik tertentu yang ditetapkan oleh peneliti untuk dipelejari dan kemudian ditarik kesimpuannya. Jadi populasi bukan hanya orang, tetapi juga obyek-obyek yang lain. Populasi juga meliputi seluruh karateristik/sifat yang dimiliki oleh subyek.Populasi dalam penelitian ini adalah siswa kelas X MAN 1 Kota Semarang tahun pelajaran 2019/2020.

\section{Sampel}

Menurut Sugiyono (2010:118) teknik sampling merupakan teknik pengambilan sampel untuk menentukan sampel yang akan digunakan dalam penelitian. Penelitian ini menggunakan teknik purporsivesampling, yakni teknik sampling yang memilih sampel berdasarkan tujuan tertentu.Oleh karena itulah, sampel dalam penelitian ini nantinya akan bergantung pada kelas yang diizinkan sekolah untukdigunakan sebagai tempat penelitian,Sample yang di gunakan pada Penelitian ini yaitu siswa kelas X MIPA diplih secara Random .

\section{Definisi Operasional}

1. Pengukuran Variabel

a. Variabel bebas

Variable bebas adalah variabel yang mempengaruhi atau yang menjadi sebab perubahannya atau timbulnya variabel dependen atau terikat (Sugiyono, 2010: Variabel bebas dalam penelitian ini yaitu teknik bola pantul dalam pembelajaran bola voli passing atas di MAN 1 Kota Semarang.

b. Variabel Terikat

Variabel terikat adalah variabel yang dipengaruhi atau yang menjadi akibat, karena adanya variabel bebas (Sugiyono, 2010: 61). Variabel terikat dalam penelitian ini pembelajaran bola voli passing atas di MAN 1 Kota Semarang.

2. Hasil Belajar

Hasil Belajar adalah suatu proses usaha yang dilakukan seseorang untuk memperoleh suatu perubahan tingkah laku yang baru secara keseluruhan, sebagai hasil pengalamannya sendiri dalam interaksi dengan lingkungannya.

3. Bola Voli

Bola voli adalah bentuk memvoli bola ke udara bolak-balik di atas jaring/net dengan maksud dapat menjatuhkan bola di dalam petak lapangan lawan untuk mencari kemenangan. Tujuan 
Peningkatan Kemampuan Psikomotorik Siswa Dalam Pembelajaran

Bola Voli Passing Atas Menggunakan Teknik Bola Pantul

Pada Siswa Kelas X Man 1 Kota Semarang

Angga Pratama, Utvi Hinda Zhannisa, Ibnu Fatkhu Royana

permainan adalah melewatkan bola di atas net agar dapat jatuh menyentuh lantai lawan. Setiap tim dapat memainkan bola tiga kali pantulan untuk mengembalikan bola.

4. Teknik Bola Pantul

Teknik bola pantul sebenarnya merupakan teknik latihan dengan cara memantulkan bola pada bidang datar vertikal (biasanya tembok). Faruq (2009:76) menuturkan teknik ini banyak digunakan oleh pemain bola voli yang sedang melatih kemampuan passing atas.

\section{Teknik dan Instrumen Pengumpulan Data}

1. Teknik Pengumpulan Data

Teknik pengumpulan data digunakan untuk mendapatkan data-data dalam penelitian. Teknik pengumpulan data dalam penelitian ini menggunakan empat cara, yakni observasi, wawancara, dokumentasi, dan tes.

\section{a. Observasi}

Teknik pengumpulan data dalam penelitian ini digunakan untuk mengamati hal-hal yang berkenaan dengan perilaku manusia, proses kerja, gajala-gejala alam dan bila responden yang diamati tidak terlalu besar (Sugiyono, 2010:203). Teknik observasi dalam penelitian ini digunakan untuk memperoleh data psikomotorik siswa. Observasi dilakukan untuk mengetahui pembelajaran bola voli, juga sarana yang mendukung hasil belajar serta pembelajaran yang digunakan dalam proses belajar mengajar di MAN 1 Kota Semarang. Observasi penelitian dilakukan untuk mengetahui permasalahan yang dapat dijadikan bahan penelitian, dan hasil observasi dari seluruh kelas X di MAN 1 Kota Semarang.

b. Wawancara

Teknik wawancara digunakan untuk mengetahui permasalahan secara lebih mendalam dari sumber data penelitian. Pada penelitian ini, dilakukan denganmewawancarai Guru dan siswa, Guru olahraga menyampaikan bahwa siswa masih kesulitan untuk menerima materi dari guru, bawasannya kurang adanya minat siswa terhadap pembelajaran penjasorkes,peneliti juga mewawancarai langsung kepada siswa yang telah mengikuti pembelajaran penjasorkes, menurut beberapa siswa materi yang diajarkan dari Guru membosankan sehingga siswa kurang adanya minat untuk mengikuti pembelajaran bola voli, sehingga mendorong peneliti untuk meningkatkan minat siswa dalam mengikuti pembelajaran voli, yakni dengan teknik passing atas menggunakan teknik bola pantul.

c. Dokumentasi

Dokumentasi digunakan untuk memperkuat data yang diperoleh dalam proses observasi. Beberapa bentuk data dokumentasi berupa berkas penilaian siswa, perangkat pembelajarn, dan berbagai hal dokumen yang terkait dengan proses penelitian.

d. Tes 
Teknik tes adalah teknik yang memanfaatkan instrumen atau alat berupa lembar tes yang digunakan untuk memperoleh informasi tentang individu atau objek. Teknik tes dalam penelitian ini berupapassing atas yang memosisikan siswa untuk melakukan passing atas dengan memantulkan ke tembok secara individu dengan pengambilan nilai yang sudah ditentukan, pengambilan data dilakukan selama 3 kali pertemuan di setiap kelasnya, kelas yang diguanakan adalah kelas X MIPA $(1,4,5)$.

\section{Teknik Analisis Data}

Pada penelitian ini teknik analisis data yang digunakan adalah teknik analisis statistik menggunakan uji-t dengan bantuan analisis statistik data SPSS.Analisis data bertujuan untuk mengetahui jawaban pertanyaan dalam penelitian.Sebelum diadakan pengujian dalam uji-t, perlu dilakukan uji prasyarat terlebih dahulu.Uji prasyarat dimaksudkan untuk mengetahui apakah data yang dianalisis memenuhi persyaratan untuk dilakukan analisis data dan pengujian hipotesis.Setelah semua uji prasyarat analisis terpenuhi, langkah berikutnya adalah analisis dengan uji-t.Uji-t untuk mengetahui ada atau tidaknya peningkatan keterampilan passing atas bolavoli siswa setelah diberikan perlakuan.

\section{HASIL DAN PEMBAHASAN}

\section{A. Deskripsi Umum Objek Penelitan}

Penelitian ini dilakukan pada tanggal 30 januari sampai dengan 14 februari 2020. Pertemuan dilakukan seminggu dua kali yaitu dihari kamis dan jumat. pengambilan data dilakukan selama 60 detik untuk setiap siswanya, setiap siswa melakukan passing atas dengan dua kali kesempatan, diambil yang tertinggi dari dua kali kesempatan tersebut. Pengambilan data dilakukan selama tiga minggu dengan tiga kali pertemuan pada setiap kelas.

Dalam pengambilan data Passing atas bola voli, minggu pertama digunakan untuk pretest dimana siswa melakukan passing atas dengan kemampuan yang dimiliki siswa. Minggu kedua dilakukan postest dengan jarak tiga meter,dan minggu ketiga dengak jarak dua meter.

\section{B. Hasil Penelitian Psikomotorik Bola Volly Passing Atas}

\section{MAN 1 Kota Semarang}

Dalam penelitian ini menggunakan Kuantitatif Deskriptif yang membahas dan mengamati tentang psikomotorik pasing atas bola volly pada siswa kelas X di MAN 1 Semarang.Dalam penelitian ini hasil yang di dapat dari data tes dan non tes dianalisis dengan seksama. Hasil data tes berupa kemampuan siswa melakukan pasing atas bola volly. Sedangkan data non tes didapat dari hasil observasi dan pengamatan secara langsung dalam proses pembelajaran yang berlangsung. 
Peningkatan Kemampuan Psikomotorik Siswa Dalam Pembelajaran

Bola Voli Passing Atas Menggunakan Teknik Bola Pantul

Pada Siswa Kelas X Man 1 Kota Semarang

Angga Pratama, Utvi Hinda Zhannisa, Ibnu Fatkhu Royana

Dalam proses pembelajaran teknik pasing atas bola volly, hal pertama yang dilakukan guru adalah guru mengucapkan salam, kemudian salah satu siswa memimpin doa. Setelah itu salah satu siswa memimpin pemanasan dan setelah itu guru memberikan apersepsi berkaitan dengan materi yang akan diajarkan.

Kegiatan inti, dalam kegiatan ini siswa diberikan permasalahan berupa pertanyaanpertanyaan yang dapat merangsang pemikiran siswa. Setelah itu guru menjelaskan teknik bola pantul passing atas bola volly. Kemudian siswa memperhatikan penjelasan guru seputar teknik bola pantul passing atas bola volly, setelah itu guru memberikan kesempatan kepada siswa untuk mengajukan pertanyaan.

Setelah tahap menanya guru memberikan kesempatan kepada siswa untuk mencoba mempratikkan olahraga teknik bola pantul ke dinding dengan media yang sudah di sediakan secara bergantian supaya paham tentang teknik pasing atas dengan menggunakan teknik bola pantul. Untuk pengambilan nilai siswa kelas X MIPA berjumlah 106 Siswa, dengan jumlah setiap kelasnya 35-36 siswa.

Setelah seluruh siswa sudah melakukan percobaan mempraktikan Passing atas bola pantul. Siswa di berikan tugas untuk melakukan pengambilan nilai pasing atas bola volly dengan teknik bola pantul tersebut .

Dalam pengambilan nilai untuk melakukan passing atas dengan teknik bola pantul. Penilaian yang diambil yakni, perkenaan tangan dengan bola, gerakan tangan, dan gerakan kaki, siswa diberikan waktu 60 detik untuk melakukan pemantulan bola kedinding yang sudah diberikan pembatas lakban hitam dengan panjang $1 \mathrm{M}$ dan lebar 1M. Pengambilan nilai dilakukan secara bersamaan sebanyak 2 siswa melakukan pemantulan bola ke dinding, dan 2 siswa lainnya menghitung secara berpasangan. Setiapsiswa mempunyai dua kali kesempatan dengan waktu 60 detik di setiap kesempatanya , nilai tertinggi akan di jadikan nilai akhir disetiap pertemuan.

Tes yang dilakukan dalam kegiatan ini yaitu tes psikomotorik. Dengan tujuan untuk meningkatkan kemampuan gerakan passing atas bola volly. teknik-teknik tolakan tolak peluru sesuai dengan arahan guru yang telah ajarkan.

\section{Hasil tes}

Hasil tes yang didapat dalam penelitian ini merupakan hasil tes setelah siswa teknik passing atas. Adapun nilai yang harus dicapai yaitu :

a. Gerakan tangan dengan baik.

b. Gerakan kaki dengan baik

c. Perkenaan bola dengan tanggan.

d. Melakukan passing atas dengan teknik bola pantul (media dinding/tembok) yang sudah di beri tanda. 
e. Tingkat keberhasilan siswa dapat dilihat dari nilai yang diperoleh siswa setelah melakukan passing atas bola volly dengan teknik bola pantul dengan memperoleh nilai sesuai dengan kriteria ketuntasan minimum (KKM) yaitu 75.

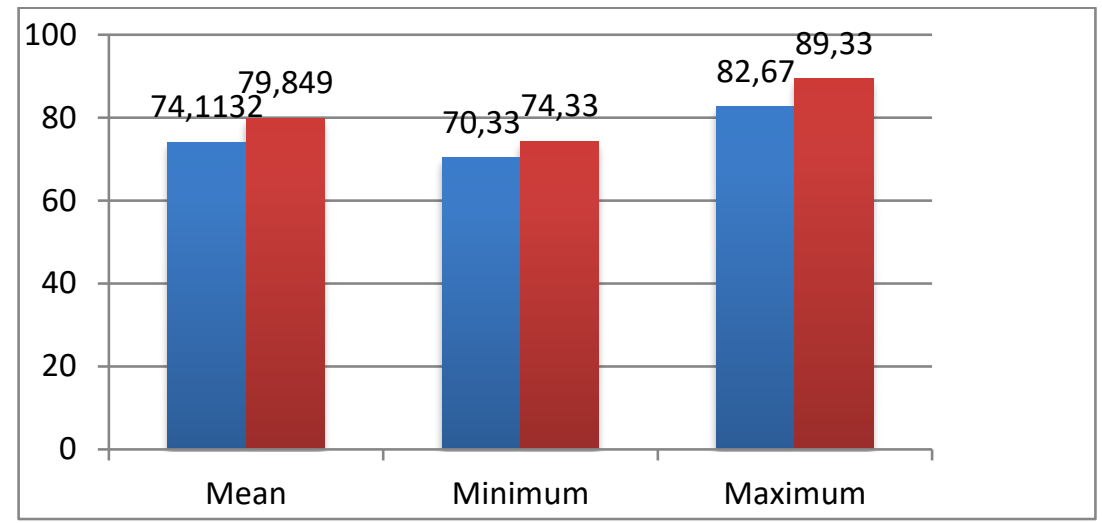

Gambar 1. Deskripsi dalam bentuk diagram batang

Berdasarkan tabel diatas diperoleh keterangan rata-rata kemampuan psikomotorik siswa sebelum diberi latihan Menggunakan teknik bola pantul adalah 74,113 dengan simpangan baku 2,55 skor minimal 70,33 skor maksimum 82,67. Rata-rata kemampuan psikomotorik siswa dalam pembelajaran bola voli passing atas setelah diberi latihan Menggunakan teknik bola pantul adalah 79,849 dengan simpangan baku 3,656 skor minimal 74,33 skor maksimum 89,33.

\section{PEMBAHASAN}

Berdasarkan hasil data peningkatan kemampuan psikomotorik siswa dalam pembelajaran bola volly passing atas menggunakan teknik bola pantul pada siswa kelas X MAN 1 Kota. Siswa terlihat aktif dan antusias dalam mengikuti pembelajaran. Siswa mampu melakukan gerakan passing atas bola voli dengan teknik bolaa pantul dengan baik dan benar.

Dengan adanya peningkatan kemampuan psikomotorik siswa dalam pembelajaran bola volly passing atas menggunakan teknik bola pantul pada siswa kelas X MAN 1 Kota. Guru dapat mengetahui apa saja kendala-kendala yang dialami oleh siswa, dapat mengetahui kemampuan siswa dalam bermain bola voli.

Pada pertemuan pertama pada saat pembelajaran berlangsung siswa melakukan teknik passing atas dengan pengetahuan yang dimiliki siswa tersebut. Pada pertemuan kedua, Siswa diberikan treatment dimana siwaa melakukan teknik passing atas bola pantul dengan jarak 3M dengan arahan dan contoh dari guru. Pertemuan terakhir siswa di berikan teritment yang sama dengan jarak yang berbeda yakni jarak 2M, dengan arahan dan contoh yang diberikan oleh guru. Berdasarkan hasil tes keterampilan di MAN 1 Kota Semarang dapat disimpulkan bahwa keterampilan olahraga bola volly yang baik yaitu :

1. Sikap badan berdiri, Kaki dibuka selebar bahu, kedua lutut agak ditekuk. 
Peningkatan Kemampuan Psikomotorik Siswa Dalam Pembelajaran

Bola Voli Passing Atas Menggunakan Teknik Bola Pantul

Pada Siswa Kelas X Man 1 Kota Semarang

Angga Pratama, Utvi Hinda Zhannisa, Ibnu Fatkhu Royana

2. Sikap kedua tangan berada di depan dahi dan badan agak condong ke depan, pandangan ke arah datangnya bola.

3. Jari-jari kedua tangan direnggangkan, perkenaan bola pada ujung jari tangan, saat perkenaan ikuti gerakan bola, kemudian dorong hingga bola melambung.

Berdasarkan hasil penelitian diperoleh keterangan modal latihan menggunakan teknik bola pantul efektif dalam meningkatkan hasil belajar bola voli passing atas pada siswa kelas X MAN 1 Semarang. Besarnya peningkatan hasil belajar setelah diberi model pembelajaran bola pantul passing atas adalah $22,38 \%$. Hasil ini menunjukkan bahwa model pembelajaran bola pantul passing atas layak untuk digunakan sebagai upaya meningkatkan hasil belajar siswa.

Tahap-tahap latihan menggunakan teknik bola pantul dilaksanakan dengan sebaik-baiknya oleh guru. Adanya RPP dan silabus menjadi salah satu bukti bahwa guru benar-benar serius dalam mengajar. Siswa benar-benar memperoleh kemudahan-kemudahan selama diajar menggunakan model latihan menggunakan teknik bola pantul. Kesuksesan proses latihan menggunakan teknik bola pantul tidak terlepas dari beberapa kendala teknis dan non teknis yang terdapat dilapangan.Bermain bola pantul merupakan bentuk latihan yang mudah dilakukan karena siswa akan memiliki banyak waktu untuk melakukan gerakan mengambil bola yang memantul kedinding. Bola yang memantul kedinding akan memberikan banyak waktu kepada siswa untuk melakukan gerakan atau teknik selanjutnya. Kemudian, dengan bermain bola pantul ini siswa akan dapat merasa lebih senang dan mudah berhasil dalam menguasai teknik dalam bermain bola voli. Dimana keberhasilan ini dapat mendorong siswa untuk mencapai keberhasilan berikutnya. Berdasarkan karakteristik permainan bola pantul diatas, maka dapat diidentifikasi kelebihannya, menurut G. Durrwachter (1990:32). Kelebihan dalam permainan bola pantul :

a. Lebih mudah dilakukan oleh anak yang belum terampil karena bola ditunggu sampai memantul dahulu sebelum di passing.

b. Pada saat bola memantul anak memiliki banyak waktu untuk mempersiapkan gerakan passing dengan baik.

c. Bola akan lebih mudah dikendalikan karena kecepatan bola semakin pelan ketika memantul ke dinding.

Sedangkan kelemahan bermain bola pantul adalah sebagai berikut :

a. Susah dilakukan jika dinding tidak rata atau tidak rapi karena bola susah dikendalikan. 
b. Jika bola kurang angin bola tidak bisa memantul dengan baik. Penguasaan teknik dasar passing atas dalam permainan bola voli adalah penting karena keberhasilan suatu team dalam pertandingan bola voli banyak ditentukan oleh passing.

Teknik passing atas selalu dipergunakan dalam permainan untuk receive servis, bertahan dari serangan lawan ataupun untuk menyusun serangan. Teknik passing atas ini harus dipelajari sejak dini dan merupakan dasar bagi atlet pemula untuk mengembangkan teknik passing atas yang lainnya. Dalam bermain bola voli atlet dituntut untuk selalu aktif bergerak di dalam lapangan. Oleh karena itu pada saat bermain bola voli arah bola yang akan di passing datangnya belum tentu sesuai dengan apa yang diharapkan, sehingga menuntut bergerak mendekat bola agar di passing dengan baik. arah bola juga harus tepat mengarah kepada pengumpan agar pengumpan lebih mudah untuk menyusun serangan atau melakukan umpan yang bervariatif, sehingga serangan tidak mudah dibaca oleh lawan. Hasil penelitian ini mendukung penelitian sebelumnya yang dilakukan oleh Ade Riska Purnama (2012). Penelitian ini bertujuan untuk mengetahui Pengaruh bermain bola pantul terhadap kemampuan dasar passing bawah peserta ekstrakurikuler bola voli putra di SMA N 7 Yogyakarta.

\section{KESIMPULAN}

Terdapat peningkatan kemampuan psikomotorik siswa dalam pembelajaran bola voli passing atas sebelum dan sesudah diberi latihan Menggunakan teknik bola pantul pada siswa kelas X MAN 1 Kota Semarang.

\section{Saran}

Sebaiknya pelatih siswa kelas X MAN 1 Kota Semarang menerapkan latihan Menggunakan teknik bola pantul mengingat latihan ini terbukti efektif dalam meningkatkan kemampuan psikomotorik siswa dalam pembelajaran bola voli passing atas.

\section{DAFTAR PUSTAKA}

Arikunto, Suharsimi. (2010). Prosedur Penelitian Suatu Pendekatan Praktik. Jakarta: Rineka Cipta.

Arrahman, Adhy B. (2015). Peningkatan Keterampilan Passing Bawah Bolavoli Dengan Menggunakan Metode Bermain Bola Pantul Peserta Ekstrakurikuler Bolavoli Putra Di Sma Negeri 1 Sirampog Brebes. Skripsi.

Beutelstahl, Dieter. (2009). BelajarBermain Bola Volley. Bandung: CV Pionir Jaya.

Faruq, M Muhyi. (2009). Meningkatkan Kebugaran Jasmani Melalui Permainan Bola Voli \& Olahraga. Jakarta: Grasindo.

Muhajir. (2013). Penjasorkes 1. Jakarta: Yudhistira.

Moh. Uzer Usman, Lilis Setiawati. (1993). "Upaya Optimalisasi Kegiatan 
Peningkatan Kemampuan Psikomotorik Siswa Dalam Pembelajaran

Bola Voli Passing Atas Menggunakan Teknik Bola Pantul

Pada Siswa Kelas X Man 1 Kota Semarang

Angga Pratama, Utvi Hinda Zhannisa, Ibnu Fatkhu Royana

Belajar Mengajar”. Bandung: PT Rosdakarya

Putra, Wicaksono. (2012). "Menentukan Sampel Dengan Rumus Slovin". Diambil dari analisisstatistika.2012/09/menentukan-jumlah-sampel-dengan-rumus.html.Diakses 02 Mei 2018.

Rahmani,Mikanda. (2014). Buku Super Lengkap Olahraga.Jakarta:Dunia Cerdas.

Sugiyono. (2006). Statistika Untuk Penelitian. Bandung: CV Alfabeta.

Syaifudin, Arif. (2015). "Upaya Meningkatkan Hasil Belajar Passing Bawah Bolavoli Melalui Permainan 5 on 5 Pada Siswa Kelas VII B Smp Negeri 16 Surakarta Tahun Pelajaran 2014/2015”. Skripsi.

Theo Kleinman, Dieter Kruber. (1984). Bola Voli Pembinaan Teknik Taktik dan Kondisi. Jakarta: PT Gramedia.

Waluyaningsih, Jati. (2014). "Meningkatkan Hasil Belajar Permainan BolaVoli Melalui Modifikasi Bola Voli Mini Siswa Kelas Iv Sdn Klatakan 02 Kecamatan Tanggul Kabupaten Jember Tahun Pelajaran 2013/2014”. Skripsi. 